\title{
Histological Study of Ovarian Interstitial Glands in IRAQI Buffaloes at Six and Nine Years Old
}

\author{
Abdul Hadi Sallal Mohammed ${ }^{1}$, Tawfeeq Jawad Ali $^{2}$ and Zainab Jawad Naki ${ }^{3}$ \\ 1. Department of Medical Labatorie, Foundation of Technical Education, College of Health and Medical Technology, Kufa, Najaf \\ 00964, Iraq \\ 2. Department of Community Health, Foundation of Technical Education, Technical Institute, kufa, Najaf 00964, Iraq \\ 3. Department of Biology, Kufa University, Girls Education College ,kufa, Najaf 00964, Iraq
}

\begin{abstract}
The present study was revealed some histological observations of interstitial glands in Iraqi buffalo's ovaries. This study was conducted on (24) ovaries collected from Al-Najaf slaughter house. The ovarian tissue specimens was fixed in (10\%) formalin and histological preparations were carried out, then stained with $\mathrm{H}$ and E. Histologically the overian buffalo cortex at six year old that revaled single glands were lined by simple cuboidal epithelial cells. The glands were surrounded by collagen fibers, blood vessels and fibroblasts. The ovarian cortex at nine years old consisted of group of interstitial glands, lined by cuboidal cells. The epithelial lining single and group of interstitial glands were filled with fat droplets. The lumen of groups of interstitial glands contains acidophilic secretion. The present study was suggested that the present of fat droplets in the cells of interstitial glands due to androgens (steroid hormones) and that ensure less fertility in the female buffaloes.
\end{abstract}

Key words: Histology, ovarian interstitial glands, buffaloes.

\section{Introduction}

The interstitial glands of the ovary are not so well defined as those in the testis. In some mammals they are referred to collectively as the interstitial glands because of their epithelial-like appearance [1].

Their prominence may vary from one species to another, as well as with stages of the reproductive cycle. Mossman et al. proposed three different glands in mammalian ovaries namely the luteal, interstitial and the thecal glands [2]. Some investigations, however after extensive light microscopic studies of mammalian ovaries failed to recognize the existence and distinctiveness of these different glands [3]. Studies of the ultarstructur of the interstitial cells have been surprisingly sparse our knowledge of these cells and their function has been more inadequate than the ovary.

Corresponding author: Abdul-Hadi Sallal Mohammed, M.D., research fields: histology sciences. E-mail: al_hadi2002@yahoo.com.
The origin of the interstitial glands of the mammalian ovary was reported by Brambell [4], Hiroshi and Keish [5]. They mentioned that primary interstitial glands in the juvenile rabbit ovary, arise from granulose cells which accumulates as nests in the medullary cords of developing rabbit ovary. The glandular interstitial tissue appeared before three month of life. Comparative study of the ovarian interstitial glands in non hibernating and hibernating mammals was conducted to determine the influnce of hibernation and Estrus cycle on the structure and function of the ovarian interstitial gland in guinea pig, rabbit, mice, bat and women [6]. The development of interstitial glands from birth to sexual maturity was observed by Takeva et al. [7].

Some histological observation on the interstitial gland in she-camel ovary was noticed by Mohammed [8].

The aim of present study is to investigate the histology of interstitial glands in the Iraqi buffaloes at six and nine years old. 


\section{Material and Methods}

The present study was designed on (12) female buffaloes, the age of animals ranged at six and nine years old. The ovarian were collected from AL-Najaf slaughter house. The age of animals were estimated according to dental formula, by experience of veternian.

The study was carried out during March and April 2010 on the animals with estrus cycles, the ovaries were removed then cleaned from adipose tissue.

The weight of left and right ovaries were taken by using sensitive balance type Sartorus.

The histological preparation included fixation the ovaries by using formalin (10\%) for $48 \mathrm{~h}$ then dehydration process have been done by using graduated concentration of ethyl alcohol $70 \%, 80 \%$, $90 \%$ and $100 \%$ for $1.5 \mathrm{~h}$ for each concentration, then the specimens were clearing by Xylene for $60 \mathrm{~min}$ for each time and then embedding with Paraffin wax. The block, where cutting by using Rotary microtome in to histological sections at $6 \mathrm{~mm}$, after that stained by Haematoxylen-Eiosin stain then mounted by Canada balsam and cover slide [9, 10].

\section{Results and Discussion}

Interstitial glands tissue has been dilemma for many investigators and is the subject of much controvert in literature due to the types of cell included in the definition of the tissue and its variability in the species [2]. In the pervious studies about glandular cells that is not a part of the theca interna or corpus luteum is classified as interstitial glands tissue [11].

These cell should not be confused with the undifferentiated stromal cell that are present in immature and mature ovarian of many species including rabbit [12], human [2] and hibernating mammals [6].

In Fig. 1, buffaloes ovary cortex at six years old shows single interstitial gland surrounded by collagen fibers and stromal cells. We suggested that interstitial tissues can be originated from various sources but in adult female buffaloes, it appears to be derived mainly from theca interna of atretic follicles and from differentiated stromal cells also. In Fig. 1, the interstitial cells at six years old filled with droplets of lipid, that ensure to synthesize and release androgen, and this suggestion is correspond with Solod et al. [13].

It has been accepted for many years that this tissue is abundant in the estrus and appears to increase during pregnancy because this progesterone is elevated and interstitial gland cells hyper atrophy [14]. These cells during this gestational period are characterized by an abundant of lipid smooth endoplasmic reticulum and mitochondria with dense matrix [15]. The functional role of 20 progesterone in ovarian activity continuous to remain unclear. It was originally believed that this hormone had a role in facilitating the release of Luteinizing hormone following coitus [14].

In Fig. 2, buffaloes ovaries cortex at nine years old shows interstitial cells lined with simple cuboidal glandular secreted epithelium and accumulation of large numbers at lumens of single interstitial glands.

The present study differed with the previous study by Mohammed. On she-camel ovary, the interstitial glands was appeared as compound-tubulo gland. The epithelial lining was cuboidal cells. When the she

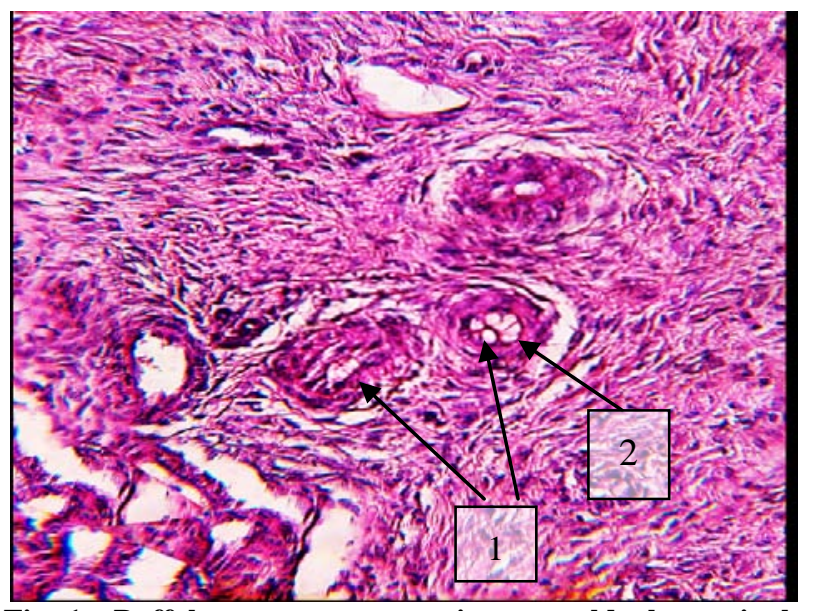

Fig. 1 Buffalo ovary cortex at six years old, shows single interstitial gland, surrounded by collagen fibers stromal cell (1), the interstitial gland filled with fat droplets (2). H\&E. 200X. 


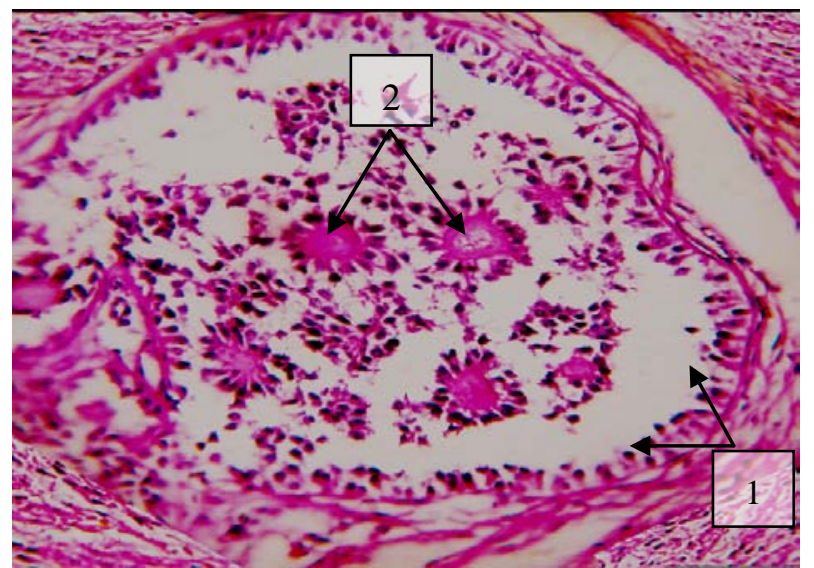

Fig. 2 Buffalo ovary cortex at nine years old. The interstitial glands lined by simple cuboidal cells (1) and gland secretion (2). H\&E. 400X.

camel advance in the age, the interstitial glands change into the simple tubular glands [8]. our observations noticed that the interstitial glands in the buffaloes ovaries were converted to groups of glandular tissue at the age of nine years old [8].

In Fig. 3, accumulation of interstitial gland which surrounded by dense connective tissues consist of collagen fibers and elastic fibers with fibrocytes and fibroblasts, and this investigation was in agreement with Takeva et al. who mentioned that an abundant epithelial cells appeared as cords in the ovaries of new born lambs [7]. Fig. 4 shows a number of small arterioles, and our observations were similar the previous study in mink ovarian cortex by Moller [16]. Many diffuse masses of large packed lipid containing cells were arranged in rows and sometime in groups, and these cells represented the ovarian interstitial glands which were lined by polygonal cells with spherical nuclei that often contained prominent nucleol. Difference in size of the cell , the nucleolus and the cytoplasm made it easy to distinguish between the different ovarian cells. Our observations was different from previous study by Mossman et al. [11], who identified three distinct types of glands cells occur in adult women ovary and other mammals. interstitial glands cells formed from theca interna cells of degenerating (atretic) follicles hence present from infancy to old age. Helical glandular cells formed from Theca interna cells of mature follicles were found only in animal that are sexually mature at time of ovulation. While previous studies [17] showed the secondary interstitial gland of the adult rabbits derived from theca interna after follicular atersia that began at three months of age. The theca interna cells differentiate to the secondary interstitial glands, and they located near to stromal or theca externa. The authors also found that the theca interna cells of atretic

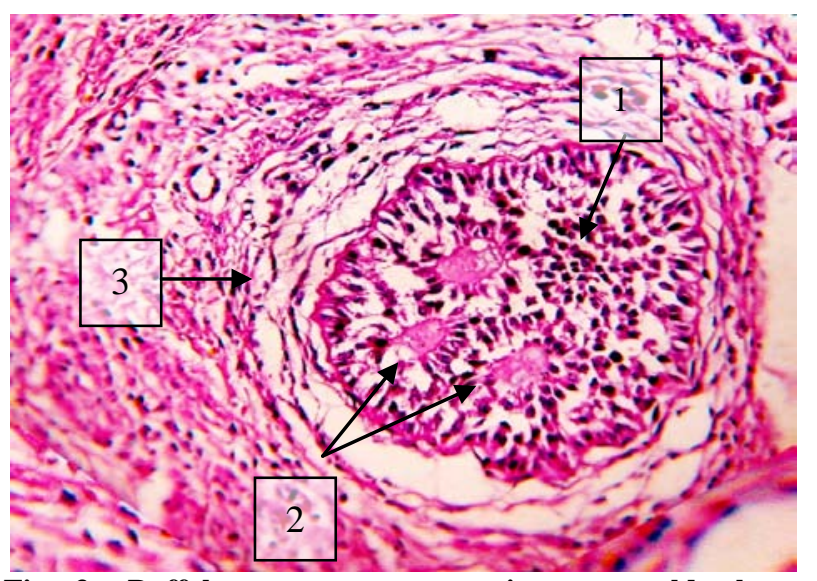

Fig. 3 Buffalo ovary cortex at nine years old, shows accumulation of large number of single interstitial gland (1), the lumens of interstitial glands had esonphilic secretion with pink color (2), accumulation of interstitial glands which surrounded by dense C.T. consist of collagen fibers and elastic fibers with fibrocytes and fibroblast (3). H\&E. 200X.

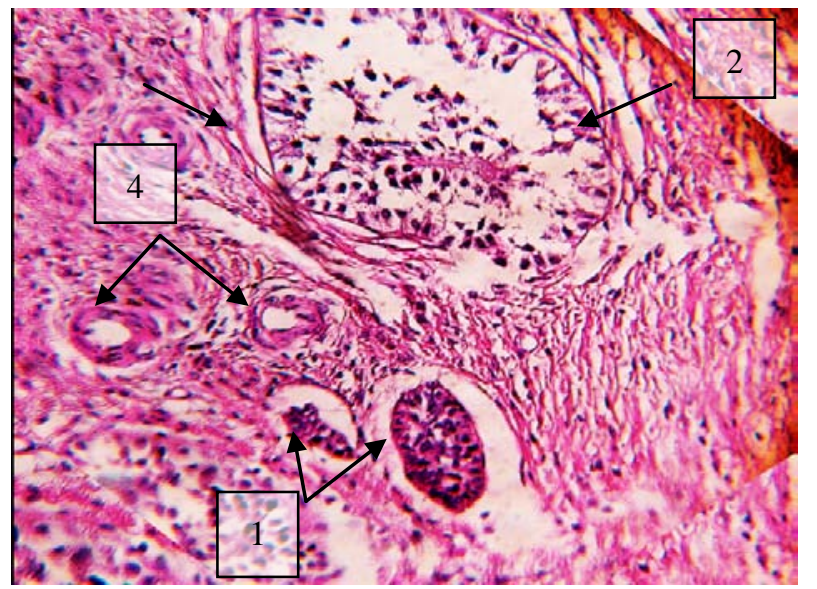

Fig. 4 Buffalo ovary cortex at nine years old, shows single interstitial glands (1), their cells which represented by stromal cells and fibroblast and accumulation of single interstitial glands (2), surrounded by C.T. (3), which consist of collagen and elastic fibers with number of small diameter arteries (4). H\&E. 200X. 
follicles did not alter directly into the secondary interstitial glandular cells at an early stage of follicular atresia. The theca interna cells under cytoplasmic hypertrophy accompanied by the appearance of the granular reticulum was after the later stage of atresia. The theca interna differentiated to secondary interstitial cells, and this phenomenon corresponds with the observations in guinea pig [18].

\section{Conclusions}

The overian buffalo cortex contains sporadic distribution interstitial glands at six years old. At nine years old, these glands were appeared as groups, lined by simple cuboidal cells, and filled by fat droplets.

\section{References}

[1] W. Bloom, D.W. Fawcett, A Textbook of Histology 9th ed., Saunders, Philadelphia, USA, 1968, p. 858.

[2] H.W. Mossman, K.L. Duke, Comparative Morphology of the Mammalian Ovary, Wisconsin University Press, Madison, USA, 1973.

[3] M. Watscka, G. Weibliche, Das Ovarian, In ltandbuch. Mikr. Anat. Menschen (in German), Springer, Berlin, 1957, p. 178.

[4] F.W.R. Brambell, Changes in Marshalls Physiology of Reproductive (ed. A.S. parkers), Vol. 1, part 1, Longmans Green, London, 1966, pp. 397-542.

[5] M. Hiroshi, M. Keish, Development of the secondary interstitial gland in the rabbit ovary, J. Anat. 116 (3) (1973) 417-430.

[6] T. Tsvetkov, V. Stanchev, T. Takva, Comparative study of the ovarian interstitial gland in hibernating mammal, Bulgarian Journal of Agricultural Science 9 (2003) 565-571.

[7] Z. Takeva, R. Georgiya, S. Bulhbel, N. Georgiva, The interstitial gland of ovary of ewes from birth to sexual maturity, Anim. Reprod. Sci. 48 (2-4) (1997) 235-246.

[8] AH.S. Mohammed, Some histological observations on the interstitial glands in she_camel ovary, Kufa Journal For Veterinary Medical Sciences 1 (1) (2010) 94-100.

[9] J.D. Bancroft, A. Stevens, The Theory and Practice of Histological Techniques, Churchill Livingstone, London, 1982, pp. 116-613.

[10] L. Vacca, Laboratory Manual of Histochemistry, Ravan press, New York, USA, 1985, p. 139.

[11] H. W. Mossman, M.J. Koering, D. Jr. Ferry, Cyclic changes of interstitial gland tissue of the human ovary, Am. J. Anat. 115 (2) (1964) 235-256.

[12] S. Nimuras, Postnatal Development of Interstitial Gland in Rabbit, Ovaries, with Particular Reference to the Ability of Steroid Genesis, Bulletin of the Faculty of Agriculture, 2001.

[13] E.A. Solod, D.T Armstrong, R.O. Creep, Action of leutinizing hormon on conversion of ovarian cholosterole stores to steroids, secreted in vivo and synthesized in vitro by the pseudopregnant rabbits ovary, Steroids 7 (6) (1966) 607-620.

[14] J. Hillard, H.G. Spies, C.H. Sawyer, Hormonal Factoryes Regulating Ovarian Choleslerole Mobilization and Progestin Secretion in Interstitial and Hypo Ghysectomized Rabbits, Appleton-Century-Crofts, New York, 1969, pp. 55-92.

[15] M.J. Koring, K.T. Kiroton, M.J. THOR, The effects of prostaglandin $\mathrm{F}_{2 \alpha}$ on the structure and function of the rabbit ovary, Biology of Reproduction 9 (3) (1973) 226-245.

[16] O.M. Moller, The fine structure of the ovarian interstitial Gland cells in the mink, Mustela vison, J. Reprod. Fert. 34 (1) (1973) 171-174.

[17] H. Mori, K. Matsumoto, Development of the secondary interstitial gland in the rabbit ovary, J. Ana. 116 (3) (1973) 471-430.

[18] R. Denesly, Origins and development of interstitial tissue in overies of rabbit and guinea, J. Ana. 113 (2) (1972) 251-260. 